\title{
Plant physiology as affected by humified organic matter
}

\section{Daniel Basílio Zandonadi1*, Mirella Pupo Santos ${ }^{2}$, Jader Galba Busato ${ }^{3}$, Lázaro Eustáquio Pereira Peres ${ }^{4}$, Arnoldo Rocha Façanha ${ }^{5}$}

'Embrapa Hortaliças, Brasília, DF, Brasil.

${ }^{2}$ Embrapa Cenargen, Brasilia, DF, Brasil.

${ }^{3}$ School of Agronomy and Veterinary Medicine, Universidade de Brasília (UnB), Brasília, DF, Brasil.

${ }^{4}$ Biological Sciences Department, Escola Superior de Agricultura "Luiz de Queiroz" (ESALQ), Universidade de São Paulo (USP),

Piracicaba, SP, Brasil.

${ }^{5}$ Center for Bioscience and Biotechnology, Universidade Estadual do Norte Fluminense "Darcy Ribeiro" (UENF), Campos dos

Goytacazes, RJ, Brasil.

*Corresponding author: daniel.zandonadi@embrapa.br

Received: February 26, 2013; Accepted: March 11, 2013

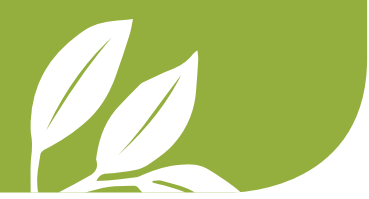

ABSTRACT: Since the beginning of Human civilization, the soil organic matter has been used as plant growth promoter and/or regulator. Indeed, early in plant science history, even before the auxin concept has been established, the term "auximones" was coined to describe plant growth promoting humic acids derived from peat. Despite of this, until the end of the $20^{\text {th }}$ century, humic substances remained as some of the most neglected environment signals in plant physiology research. However, this scenario has changed in last decade with the discovery that the major systems of energy transduction of the plant cell membranes, the proton pumps, can be tightly orchestrated by humic substances just as elicited by a hormonal signaling. Differential activations of both plasma membrane (PM $\left.\mathrm{H}^{+}-\mathrm{ATPase}\right)$ and vacuolar pumps (V-ATPase and $\mathrm{H}^{+}$-PPase) are modulated by humic substances triggering ion signatures related to specific patterns of plant growth and development. Phytohormones have been found to be associated with this humus bioactivity, and nitric oxide acting as a second messenger in a signaling pathway in which plants can sense the soil environment to cope with specific conditions. In this review, we discuss some of the most influential data available in literature, which have shaped this underexplored interface between the chemistry of the organic matter and the plant physiology. The key role of organic matter in the sustainable agriculture will also be highlighted from a biochemical perspective of the plant cell responses to biofertilization, specially in tropical environments.

KEYWORDS: auxin, biofertilizer, humus, proton pumps, vegetables, vermicompost.

\section{INTRODUCTION}

In the late 1800s, Charles Darwin had reported seminal data on the significance of earthworms in soil and humus formation (Darwin 1881), and discussed the so called transmittable influence observed in plants related to movements in radicles, epicotyls and hypocotyls (Darwin 1880). Remarkably, the effects of endogenous plant hormone auxin during seedling growth and the dark-colored humus from natural earthworm action were first reported almost simultaneously (Darwin 1880,1881 ), and its role in humic substances (HS) bioactivity was established in the following century (Bottomley 1917, Guminski 1968, Dell'Agnola and Nardi 1987).

Long before the discovery of most classical hormones, external signals derived from the environment were already described as plant growth regulators (Bottomley 1914, 1915, 1917, Mockeridge 1920). In fact, even before Went (1926) and Kogl and Haagen-Smit (1931) name the transmittable influence observed by Darwin as auxin, Bottomley $(1915,1917)$ suggested the term "auximones", meaning "growth promoting" to designate "humic-acids" isolated from peat. 
Nowadays, there are still relatively fewer studies on natural environmental-derived humic substances as compared to the profusion of studies on endogenous phytohormones. Much of this lack of information on these complex substances continue to be accounted to the same reasons summarized by Bottomley almost one hundred year ago:

The true nature of the dark brown and black substances formed by the decomposition of organic matter in the soil, and grouped together under the collective name of humus, has long been a problem to both chemists and biologists, owing to the fact that the composition of these substances varies not only with the nature of the humus-producing materials, but also with the temperature, moisture and pressure relations, and the methods of extraction (Bottomley 1915, p. 260).

Indeed, the source of humus and the extraction methods are issues not well standardized in several works addressing the humic substances effects on plant physiology. These substances are the major components of stabilized organic matter, widely spread in terrestrial and aquatic environments (Stevenson 1994) with several functions on ecological systems, affecting biochemical and biogeochemical pathways (Steinberg et al. 2006). Hereby, the term "humus" shall be considered as synonymous of humified organic matter or HS, the relatively stabilized organic compounds in soil, sediments or water, resulted from plants and animals residues transformed through interactions with microorganisms and minerals.

The role of humified organic matter on organic carbon biogeochemistry, atmospheric $\mathrm{CO}_{2}$, pollutants fate and plant growth is very important for sustaining life on planet (Piccolo 1996, Piccolo et al. 2004). Regarding the lifecycle of higher plants, the possible linkage of auxin and organic matter content in soils has beenlong recognized (Whitehead 1963, O'Donnell 1973). These findings are in line with the notion that HS are endowed with hormone-like activities (Guminski 1968, Schnitzer and Poapst 1967, Cacco and Dell'Agnola 1984, Muscolo et al. 1998, Nardi et al. 2000, Canellas et al. 2002, Elena et al. 2009, Zandonadi et al. 2010). Even after a number of evidences have shown that both low molecular weight (LMW) HS as well as high molecular weight (HMW) HS could regulate the plant growth and physiology, the biological activity/molecular weight paradigm remains alive. Until the mid of 1980s, most of the works were carried out with humic acids, known as HMWHS (Vaughan and Malcolm 1985 and references therein). However, after that, the dominant concept regarding the hormone-like or biological activity of HS was focused on the LMWHS, considered to be more accessible by the plant cell (Cacco and Dell'Agnola 1984, Dell'Agnola and Nardi 1987, Pinton et al. 1998, Nardi et al. 2005). In fact, these reports provided some evidences on this hypothesis and brought up an important discussion on plant accessibility to HS extracted from soils. However, it is worth noting that these data were obtained with $\mathrm{HS}$ isolated using synthetic concentrated alkalis (e.g., $0.5 \mathrm{~mol} \mathrm{~L}^{-1} \mathrm{NaOH}$ or $\mathrm{KOH}$ ), conditions never found in the chemical environment of rhizosphere of the plants (milimolar of organic acids in water solutions). It is also argued that HS could not reach the interior of plant cell, and their observed effects should be regarded to other factors such as the HS release of ions and nutrient availability (Chen and Aviad 1990, Chen et al. 2004).

The controversy on the relationships between HS chemical structure and biological activity has indeed received an increasing attention. On the other hand, much less interest has been directed towards the development of ecologically friendly and economically viable technologies for HS use in field or agricultural practices to enhance cultivated soil quality. This is particularly important for tropical countries with overuse of synthetic fertilizers. Recent studies have demonstrated that both consumption and prices of non-renewable fertilizers has been increasing as well as has occurred with the Food and Agriculture Organization (FAO) Food Price Index (FAO 2010). The Brazilian fertilizer scenario is alarming, since the country imports at least $75 \%$ of nitrogen, $50 \%$ of phosphorus and $90 \%$ of potassium as fertilizers (Finance Ministry 2011). Beyond the economical and political issues, the increase of soil salinity and the eutrophication of groundwater are among the most dangerous environmental problems related to this intensive chemically fertilization of the fields (Hoben et al. 2011, Novotny 2011).

The roots of a new "Green Revolution" might be related to technologies to reduce fertilizer inputs (Gutiérrez-Miceli et al. 2011, Yadav and Garg 2011). Herder et al. (2010) have reported that root architecture and nutrients uptake are directed affected by humus, enhancing plant yield. Indeed, organic composts, and domestic or agricultural organic wastes have proved to be powerful sources of natural organic fertilizers (Arteaga et al. 2007, Gutiérrez-Miceli et al. 2011, Ortega and Fernández 2007, Busato et al. 2012, Zandonadi and Busato 2012), with biological properties on plant physiology, not found in regular fertilizers (Zandonadi and Busato 2012). The huge amount of organic residues from poultry, pork and cattle production may also help to meet the fertilizer needs for the increasing demand of worldwide agriculture. In Brazil, it is generated around 1.7 billion tons per year of waste considering the total from poultry, pork and cattle (IPEA 2012). In order to give the best route for this enormous amount of residues, new technologies are needed, which in turn could help farmers to cope with the high cost of imported fertilizers. 
The biological activity or the so called physiological or hormone-like effects of organic matter is one of the major positive differences of the organic fertilizers as compared to chemical fertilizers. Thus, this is of remarkable importance for plant development, once it may affect not only plant nutritional aspects, but also plant response to environment challenges. The reactions of plants to endogenous and environmental signals are related to the presence of molecules used as chemical messengers (Swarup et al. 2002). Plant hormones such as auxin, gibberellin, and abscisic acid are able to regulate the activity of the proton pumps eliciting key physiological responses (Marré and Ballarin-Denti 1985). Plants regulate the interaction of their proton pumps in order to respond to the constant environmental changes. At the same time, they preserve optimal metabolic conditions for growth and development (Serrano 1989, Gaxiola et al. 2007). Therefore, it is not surprising that likely other signals, several organic matter fractions can affect the electrochemical gradient of protons across the cell membranes via modulation of the proton pumps. In this regard, HS affect this enzyme activity, protein expression, proton extrusion (Canellas et al. 2002, Façanha et al. 2002) and mRNA levels (Quaggiotti et al. 2004, Elena et al. 2009) of plasma membrane proton ATPase (PM H ${ }^{+}$-ATPase),

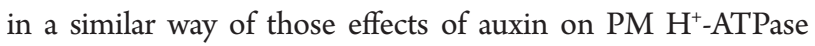
reported in maize (Frías et al. 1996). This enzyme plays a crucial role on nutrient uptake and root growth, as confirmed by its abundance in root tissues (Palmgren 2001).

In addition, the vacuolar $\mathrm{H}^{+}$-PPase (type $1 \mathrm{H}^{+}$-PPase, AVP1) has been reported as important to the regulation of apoplastic $\mathrm{pH}$ and to auxin transport ( $\mathrm{Li}$ et al. 2005), and has also been strongly related to plant capacity to cope with low amounts of $\mathrm{PO}_{4}$ and $\mathrm{NO}_{3}$ in phosphorous- and nitrogen-deprived environments (Yang et al. 2007, Gaxiola et al. 2012, Paez-Valencia et al. 2013) — a very common problem in tropical soils. There is only one work in literature reporting the action of HS on plant $\mathrm{H}^{+}$-PPase (Zandonadi et al. 2007). This enzyme seems to be of remarkable importance in humus effects on plant physiology, but a whole picture depicting the role of this enzyme in the complex mechanism of action of humus plant growth regulation will require further extensive researches. In this review, the main data available on the central role of the proton pumps in plant physiology as affected by HS are compiled towards to reveal the complex network related to their hormone-like activities.

\section{CHEMICAL CHARACTERISTICS AND EXTRACTION METHODS}

Even after several decades of research and thousands of publications involving the subject, the HS chemistry is still regarded as one of the least understood and more complex chapters in the environmental sciences. This can be easily observed when its structure and conformation are focused. New and old concepts have shown different evidences about macromolecular, micellelike or supramolecular properties, but the complexity and diversity of HS has not allowed, up to now, a detailed and unequivocal description of the structural basis of their bioactivity. Although it is not a new subject, the extension with which the HS regulate plant growth is still far from being completely elucidated. Part of the problem occurs due to the use of very different sources, highlighting the HS natural complexity. Materials with quite different physical-chemical properties are experimentally treated as belonging to a homogeneous HS class resulting in characterizations of diverse, often contradictories, biochemical and agronomical properties.

Most data describing plant growth stimulation refers to humic fractions obtained from the procedure described by the International Humic Substance Society (IHSS), which is based on the solubility of HS in alkaline aqueous solution prepared with $\mathrm{NaOH}$, but pyrophosphate solution is also frequently used. Following extraction (usually at a 1:20 ratio), the $\mathrm{pH}$ of the solution is acidified to obtain the precipitate named humic acids (HA), which are heterogeneous mixtures of oxidized organic material having various molecular moieties and functional groups (Stevenson 1994). Their molecular sizes can reach several hundred thousand Daltons $(\mathrm{Da})$, giving rise to a structure usually reported as macromolecular. Cameron et al. (1972) suggested that the HA molecules in HS had massweighed average molecular masses of 20,000-50,000 Da. The molecular parameters of HA were thriving established by Orlov et al. (1975), who aimed to determine the limiting values for the HA molecular weights and revealed a range of values, being one of the first groups to verify the supramolecular organization of HA. The supramolecular concept was further developed to describe the apparent macromolecular structure of HA as aggregates of organic molecules derived from plants and microorganisms, which exhibit diverse size and chemical composition, associated by hydrogen bonds and hydrophobic interactions, forming a structure with a central hydrophobic domain (Piccolo 2001, Simpson et al. 2002). Organic acids present in the soil-plant interface could promote the rupture of this humic aggregate, allowing plants to access bioactive substances that can induce morphological, physiological and biochemical adaptive responses.

Meanwhile, several evidences have suggested that water extractable humic substances (WEHS fractions) could also act as plant growth promoters (Pinton et al. 1998, 1999, Schmidt et al. 2007). The molecular weight distribution of the WEHS fraction, much less polydispersed than that of humic and fulvic acids extracted with alkaline solutions, shows more than 
$80 \%$ of molecules with apparent molecular weight less than 2,500 Da (Tomasi et al. 2013). In pyrophosphate solution, most of the humic molecules present molecular weight greater than 5,000 Da (Pinton et al. 1998). Low weight organic molecules have been pointed as responsible for the stimulatory effect on plasma membrane $\mathrm{H}^{+}$-ATPase and inductor of specific modification of cell membrane permeability (Varanini et al. 1993). On the other hand, Canellas et al. (2008a) evaluated the relationship between chemical properties of size-fractions of HA extracted from vermicompost and their effects on plant root growth, and concluded that molecular size distribution is not a primary factor related to the root growth.

Elemental composition analysis showed that WEHS are depleted in carbon and nitrogen, but more enriched in oxygen than pyrophosphate-extractable humic substances (Pinton et al. 1998). The high O content can point to a higher oxidation level of WEHS than $\mathrm{HA}$ obtained using $\mathrm{NaOH}$ procedure, suggesting a high total acidity or cation exchange capacity. Farther, the Fourier-Transform Infrared Spectroscopy spectra of WEHS display typical absorption bands of fulvic acids, a humic fraction usually reported as of lower molecular weight and size than HA (Stevenson 1994), but often overlooked in plant growth experiments. Strong absorption near $1,720 \mathrm{~cm}^{-1}$ due to $\mathrm{C}=\mathrm{O}$ stretching of $\mathrm{COOH}$ and a weaker $1,620 \mathrm{~cm}^{-1}$ band (aromatic $\mathrm{C}=\mathrm{C}$ and strongly $\mathrm{H}$ bonded $\mathrm{C}=\mathrm{O}$ ) as well as a $\mathrm{CO}$ stretching and $\mathrm{OH}$ deformation of $\mathrm{COOH}$ at $1,226 \mathrm{~cm}^{-1}$ was observed in the WEHS extracted from finely ground sphagnum peat (Tomasi et al. 2013). The functional carboxylic and hydroxyl groups present in humic material could play a major role in its activity (Vaughan and Malcolm 1985). Thus, LMW fractions would have a higher metal binding capability, which could account for their ability in improving nutrient assimilation. In this regard, Tomasi et al. (2013) showed that iron from Fe-WEHS could be efficiently acquired in a mixture of natural Fe complexes possibly occurring in the rizosphere.

Canellas et al. (2008a) studied the bioactivity and chemical characteristics of $\mathrm{NaOH}$-soluble $\mathrm{HS}$ from a sequence of tropical soils and observed that the degree of hydrophobicity and the acidic functional groups of this humic fraction were features that could be related to its capacity to promote plant growth. HA isolated from highest weathered soils (high carboxylic acidity) generally exhibited both lower molecular weight and bioactivity. Conflicting results, on the other hand, showed that hydrophilic and less-structured water-soluble fractions were more effective in improving both growth and enzymatic activities of plants (Vaccaro et al. 2009). It was suggested that composted organic matter could be useful for plant growth stimulation if the content of potentially bioavailable hydrophilic and less structured fractions is higher enough.
However, Canellas et al. (2008a) have extracted and characterized a $\mathrm{NaOH}$-soluble humic fraction from soils followed by strong acidification to obtain HA, differing from Vaccaro et al. (2009), which have extracted and characterized water-soluble humic fractions from compost. These and other major differences between these works make a direct comparison quite challenging. Nevertheless, even when the HS fraction is the one with apparent HMW such as HA, the characteristics of hydrophilic and hydrophobic components and its role in plant metabolism point to a long discussion, since one states that "the larger the hydrophobic components in humic samples, the lower becomes the activity of HS on plant physiology" (Nardi et al. 2007), while other authors go to the opposite direction (Canellas et al. 2008a).

Such observations reinforced the notion that the humic matter chemical composition is not enough to estimate its plant growth promoting activity. For instance, Nardi et al. (2000) showed that both LMW and HMW humic fraction could positively influence the metabolic parameters of Pinus. The plant species differ in their capacity to respond to biological humus activity pinpointing a complex relationship involving plants, humic material and environment.

\section{HUMUS EFFECTS ON PLANT PHYSIOLOGY}

What are the mechanisms of action of humus? And how it affects plant physiology? Table 1 is an attempt to gather together the most relevant literature available on the humus effects on plant proton pumps and/or on the HS hormone-like activity. Taking together these data, it is possible to postulate a putative mechanism of action for humus bioactivity on the plant cell and root development (Figure 1).

Evidences for the hormone-like activity of humus: During the summer of 1913, in England, Professor William B. Bottomley made a number of experiments with plants, to test the value of Sphagnum peat as fertilizer. This material was incubated with a mixed culture of aerobic soil organisms and apparently the material called "humic acid" in the peat was converted into "soluble humates" (Bottomley 1914, p. 239). This material was essentially described as "an aqueous extract of the alcohol-soluble material of the bacterised peat" (Bottomley 1914), considered as an excellent culture medium for nitrogen fixing bacteria Azotobacter chroococcum and wheat seedlings growth, apparently containing the so called "accessory factors" besides the mineral factors used. Since the knowledge of physiology of plants was emerging at that time, the concept of plant hormones per se was not fully established. Interestingly, Bottomley suggested that the effects of peat could be related to the phosphorus metabolism. It was concluded that the "active 
Table 1. Reports of humic substances effects on plant growth regulation via hormone-like activity and proton pump activation

\begin{tabular}{|c|c|c|c|c|c|c|c|c|c|c|}
\hline \multicolumn{3}{|c|}{ Humic substances } & \multirow{2}{*}{ Treatment } & \multirow{2}{*}{$\begin{array}{c}\text { Plant } \\
\text { material }\end{array}$} & \multirow{2}{*}{\multicolumn{3}{|c|}{ Pump activity (\%) }} & \multicolumn{2}{|l|}{ Effects } & \multirow{2}{*}{ Reference } \\
\hline Source & Size & Dose & & & & & & Nutrient \& others & Hormonal & \\
\hline Podzol Soil & $\begin{array}{c}\text { Unfractionated } \\
>100 \mathrm{kDa} \\
<9 \mathrm{kDa}\end{array}$ & $25 \mathrm{mg} \mathrm{C} \mathrm{L}^{-1}$ & $\begin{array}{l}20 \text { min, } \\
\text { in vitro }\end{array}$ & A. sativa & $\begin{array}{l}-41 \\
-34 \\
-27\end{array}$ & $\begin{array}{l}\text { N/V } \\
\text { N/V } \\
\text { N/V }\end{array}$ & $\begin{array}{l}\text { N/V } \\
N / V \\
N / V\end{array}$ & $\begin{array}{l}\mathrm{K}^{+} \text {and } \mathrm{SO}_{4} \text { uptake } \\
\mathrm{K}^{+} \text {and } \mathrm{SO}_{4} \text { uptake } \\
\mathrm{K}^{+} \text {and } \mathrm{SO}_{4} \text { uptake }\end{array}$ & $\begin{array}{l}\text { N/V } \\
\text { N/V } \\
\text { N/V }\end{array}$ & $\begin{array}{l}\text { Maggioni } \\
\text { et al. } 1987\end{array}$ \\
\hline Vermicompost & $\begin{array}{c}\text { Unfractionated } \\
>100 \mathrm{kDa} \\
<9 \mathrm{kDa}\end{array}$ & & $20 \mathrm{~min}$, in vitro & A. sativa & $\begin{array}{l}-27 \\
-24 \\
-27\end{array}$ & $\begin{array}{l}\mathrm{N} / \mathrm{V} \\
\mathrm{N} / \mathrm{V} \\
\mathrm{N} / \mathrm{V}\end{array}$ & $\begin{array}{l}\text { N/V } \\
\text { N/V } \\
\text { N/V }\end{array}$ & $\begin{array}{l}\mathrm{K}^{+} \text {and } \mathrm{SO}_{4} \text { uptake } \\
\mathrm{K}^{+} \text {and } \mathrm{SO}_{4} \text { uptake } \\
\mathrm{K}^{+} \text {and } \mathrm{SO}_{4} \text { uptake }\end{array}$ & $\begin{array}{l}\text { N/V } \\
\text { N/V } \\
\text { N/V }\end{array}$ & \\
\hline Vermicompost & $\begin{array}{l}>3.5 \mathrm{kDa} \\
<3.5 \mathrm{kDa}\end{array}$ & $\begin{array}{c}1.1-10 \mathrm{mg} \\
C L^{-1} \\
1.1-10 \mathrm{mg} \\
C L^{-1}\end{array}$ & $5 \mathrm{~h}$, in vivo & A. sativa & $\mathrm{N} / \mathrm{V}$ & N/V & $\mathrm{N} / \mathrm{V}$ & $\begin{array}{l}\mathrm{NO}_{3} \text { uptake } \\
\mathrm{NO}_{3} \text { uptake }\end{array}$ & $\begin{array}{l}\text { IAA, GA } \\
\text { and CK } \\
\text { IAA, GA } \\
\text { and CK }\end{array}$ & $\begin{array}{l}\text { Dell'Agnola and } \\
\text { Nardi, } 1987\end{array}$ \\
\hline $\begin{array}{l}\text { Sphagnum } \\
\text { peat }\end{array}$ & $<5 \mathrm{kDa}$ & $0.5 \mathrm{mg} \mathrm{L}^{-1}$ & $\begin{array}{l}5 \text { min, } \\
\text { in vitro }\end{array}$ & A. sativa & 35 & 35 & $\mathrm{~N} / \mathrm{V}$ & $\mathrm{H}^{+}$extrusion & N/V & $\begin{array}{c}\text { Pinton et al. } \\
1992\end{array}$ \\
\hline \multirow{2}{*}{$\begin{array}{l}\text { Lythic rendoll } \\
\text { soil }\end{array}$} & $<5 \mathrm{kDa}$ & $\begin{array}{c}0.075 \mathrm{mg} \\
\mathrm{C} \mathrm{L}^{-1}\end{array}$ & $\begin{array}{l}20 \text { min, } \\
\text { in vivo }\end{array}$ & A. sativa & 435 & N/V & $\mathrm{N} / \mathrm{V}$ & $\mathrm{NO}_{3}$ uptake & N/V & \multirow{2}{*}{$\begin{array}{c}\text { Varanini et al. } \\
1993\end{array}$} \\
\hline & $>5 \mathrm{kDa}$ & $0.5 \mathrm{mg} \mathrm{C} \mathrm{L}^{-1}$ & $\begin{array}{l}20 \mathrm{~min}, \\
\text { in vitro }\end{array}$ & A. sativa & 30 & N/V & $\mathrm{N} / \mathrm{V}$ & $\mathrm{NO}_{3}$ uptake & $\mathrm{N} / \mathrm{V}$ & \\
\hline Vermicompost & $<3.5 \mathrm{kDa}$ & & & & $\mathrm{N} / \mathrm{V}$ & $\mathrm{N} / \mathrm{V}$ & N/V & N/V & IAA & $\begin{array}{l}\text { Muscolo } \\
\text { et al. } 1998\end{array}$ \\
\hline $\begin{array}{l}\text { Sphagnum } \\
\text { peat }\end{array}$ & WEHS & $5 \mathrm{mg} \mathrm{C} \mathrm{L}^{-1}$ & $4 \mathrm{~h}$, in vivo & Zea mays & 28 & $\mathrm{~N} / \mathrm{V}$ & $\mathrm{N} / \mathrm{V}$ & $\mathrm{NO}_{3}$ and $\mathrm{NH}_{4}^{+}$ & N/V & $\begin{array}{c}\text { Pinton et al. } \\
1999\end{array}$ \\
\hline Cambisol soil & LMW & $0.1 \mathrm{mg} \mathrm{L}^{-1}$ & $16 \mathrm{~h}$, in vivo & Z. mays & 89 & N/V & $\mathrm{N} / \mathrm{V}$ & $\mathrm{NO}_{3}$ uptake & GA & $\begin{array}{l}\text { Nardi et al. } \\
2000\end{array}$ \\
\hline Vermicompost & HMW & $20 \mathrm{mg} \mathrm{C} \mathrm{L}^{-1}$ & $7 \mathrm{~d}$, in vivo & Z. mays & 66 & $\mathrm{~N} / \mathrm{V}$ & $\mathrm{N} / \mathrm{V}$ & $\mathrm{H}^{+}$extrusion & IAA & $\begin{array}{l}\text { Canellas } \\
\text { et al. } 2002\end{array}$ \\
\hline Vermicompost & $<3.5 \mathrm{kDa}$ & $\begin{array}{c}0.75 \mathrm{mg} \\
\mathrm{CL}^{-1}\end{array}$ & 48h, in vivo & Z. mays & $\mathrm{N} / \mathrm{V}$ & $\mathrm{N} / \mathrm{V}$ & N/V & $\mathrm{NO}_{3}$ uptake & IAA & $\begin{array}{l}\text { Quaggiotti } \\
\text { et al. } 2004\end{array}$ \\
\hline Vermicompost & HMW & $20 \mathrm{mg} \mathrm{C} \mathrm{L}^{-1}$ & $5 \mathrm{~d}$, in vivo & Z. mays & 89 & 166 & 23 & $\mathrm{H}^{+}$extrusion & IAA & $\begin{array}{l}\text { Zandonadi } \\
\text { et al. } 2007\end{array}$ \\
\hline Sewage sludge & HMW & $20 \mathrm{mg} \mathrm{C} \mathrm{L}^{-1}$ & $5 \mathrm{~d}$, in vivo & Z. mays & 191 & 113 & 46 & $\mathrm{H}^{+}$extrusion & IAA & \\
\hline Ultisol soil & HMW & $20 \mathrm{mg} \mathrm{C} \mathrm{L}^{-1}$ & $5 \mathrm{~d}$, in vivo & & 75 & 173 & 146 & $\mathrm{H}^{+}$extrusion & IAA & \\
\hline Incept Soil & HMW & $20 \mathrm{mg} \mathrm{C} \mathrm{L}^{-1}$ & $5 d$, in vivo & Z. mays & 196 & 60 & 123 & $\mathrm{H}^{+}$extrusion & IAA & \\
\hline $\begin{array}{l}\text { Sphagnum } \\
\text { peat }\end{array}$ & WEHS & $50 \mathrm{mg} \mathrm{L}^{-1}$ & 8h, in vivo & $\begin{array}{c}\text { Arabidopsis } \\
\text { thaliana }\end{array}$ & $\mathrm{N} / \mathrm{V}$ & N/V & N/V & N/V & $\begin{array}{l}\text { No auxin } \\
\text { activity }\end{array}$ & $\begin{array}{l}\text { Schmidt } \\
\text { et al. } 2007\end{array}$ \\
\hline \multirow{3}{*}{ Oxisol soils } & HMW & $3-300 \mathrm{mg} \mathrm{L}^{-1}$ & $2 \mathrm{w}$, in vivo & A. Thaliana & N/V & N/V & $\mathrm{N} / \mathrm{V}$ & N/V & IAA & \multirow{3}{*}{$\begin{array}{c}\text { Dobbss et al. } \\
2007\end{array}$} \\
\hline & & $40 \mathrm{mg} \mathrm{L}^{-1}$ & $10 \mathrm{~d}$, in vivo & $\begin{array}{c}\text { Solanum } \\
\text { lycopersicum }\end{array}$ & $N / V$ & $\mathrm{~N} / \mathrm{V}$ & N/V & N/V & IAA & \\
\hline & LMW & $3-300 \mathrm{mg} \mathrm{L}^{-1}$ & $2 \mathrm{w}$, in vivo & A. Thaliana & $N / V$ & $\mathrm{~N} / \mathrm{V}$ & $\mathrm{N} / \mathrm{V}$ & $\mathrm{N} / \mathrm{V}$ & IAA & \\
\hline
\end{tabular}

Several proteins expression, including

Vermicompost Unfractionated $1 \mathrm{mg} \mathrm{CL}^{-1} \quad 16 \mathrm{~h}$ in vivo $\quad \mathrm{Z}$ mays $\mathrm{N} / \mathrm{V} \mathrm{N} / \mathrm{V} \quad \mathrm{N} / \mathrm{V}$ those related to auxin

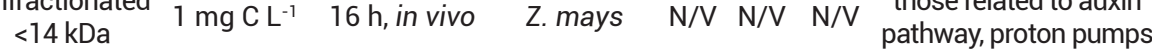
and nutrient metabolism and uptake.

$\mathrm{NO}_{3}$ uptake and

Leonardite HMW $5 \mathrm{mg} \mathrm{L}^{-1} 48 \mathrm{~h}$, in vivo $\begin{gathered}\text { Cucumis } \\ \text { sativus }\end{gathered} 130 \mathrm{~N} / \mathrm{V} \mathrm{N} / \mathrm{V} \quad \begin{gathered}\mathrm{NO}_{3} \text { enzymes of } \mathrm{N} \\ \text { metabolim }\end{gathered}$
metabolim

$\begin{array}{lllll}\text { Leonardite } \quad \mathrm{HMW} \quad 5 \mathrm{mg} \mathrm{L}^{-1} & 48 \mathrm{~h} \text {, in vivo } & \text { C. sativus } 135 \mathrm{~N} / \mathrm{V} \quad \mathrm{N} / \mathrm{V} & \begin{array}{c}\text { Nutrients analysis, } \mathrm{NO}_{3} \\ \text { uptake and enzymes }\end{array}\end{array}$ of $\mathrm{N}$ metabolim

\begin{tabular}{|c|c|c|c|c|c|c|c|}
\hline Vermicompost & HMW & $20 \mathrm{mg} \mathrm{C} \mathrm{L}^{-1}$ & $4 \mathrm{~d}$, in vivo & Z. mays & 50 & $\mathrm{~N} / \mathrm{V}$ & $\mathrm{N} / \mathrm{V}$ \\
\hline Vermicompost & $>3.5 \mathrm{kDa}$ & $\begin{array}{c}0.5-2.0 \mathrm{mg} \\
\mathrm{CL}^{-1}\end{array}$ & $48 \mathrm{~h}$, in vivo & Z. mays & N/V & N/V & N/V \\
\hline
\end{tabular}

$\mathrm{H}^{+}$extrusion

$\mathrm{N}$ metabolism, secondary metabolism HS function by auxin dependent and independent, nutrients uptake, vesicle

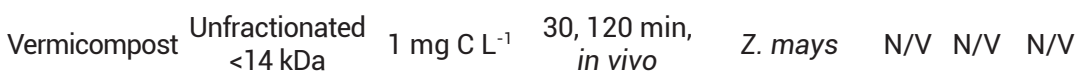
trafficking, transport mechanism, gene transcription and protein regulation

\begin{tabular}{|c|c|c|c|c|c|c|c|c|c|c|}
\hline Leonardite & HMW & $100 \mathrm{mg} \mathrm{L}^{-1}$ & $72 \mathrm{~h}$, in vivo & C. sativus & $\mathrm{N} / \mathrm{V}$ & $\mathrm{N} / \mathrm{V}$ & N/V & $\mathrm{N} / \mathrm{V}$ & $\begin{array}{l}\text { IAA, ET } \\
\text { and NO }\end{array}$ & $\begin{array}{c}\text { Mora et al. } \\
2012\end{array}$ \\
\hline
\end{tabular}

N/V: not verified; IAA: indole acetic acid; ET: ethylene; GA: gibberellic acid; CK: citokynin; PA: polyamines; ABA: abscisic acid; WEHS: water extractable humic substances; HMW: high molecular weight; LMW: low molecular weight. 

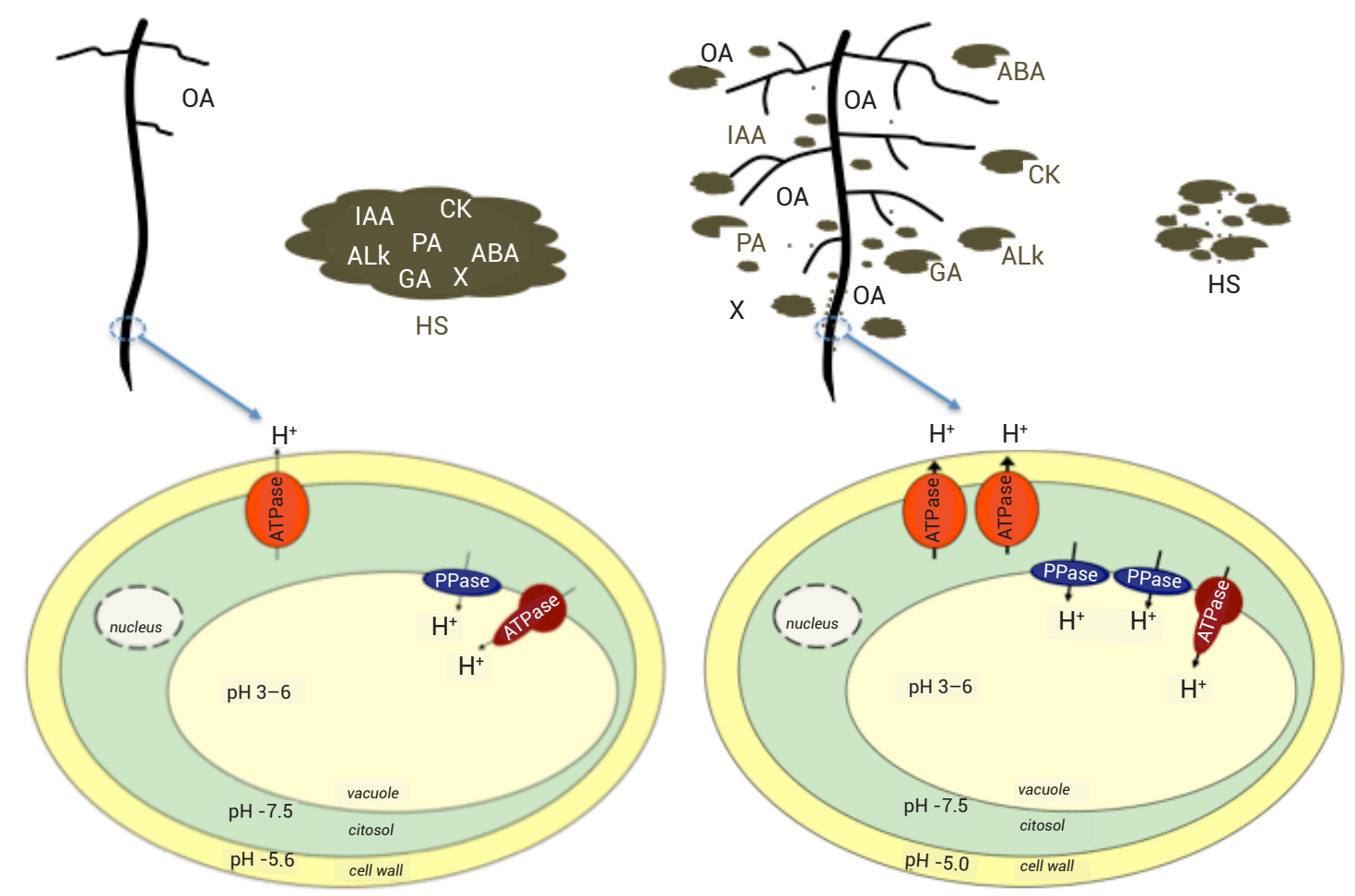

Figure 1. Hypothesis of the humic substances (HS) interaction with plant roots and its effects on plant physiology. HS action on plant might be related to either phytohormones released from its structure in rhizosphere during interaction with plants - which can release organic acids (OA) in response to HS and microorganisms - and/or phytohormones-like molecules direct from the humic structure. In either cases, the role of plant proton pumps appear to be very important to root growth and morphology, besides nutrient uptake. The size of whole HS and its fractions may represent the diversity of molecular size of HS in rhizosphere. HS may affect plant physiology by regulating pumps activity, expression and transcription, and possibly a plethora of phytohormones and hormone-like substances that may trigger nitric oxide production. IAA: indole acetic acids; ABA: abscisic acid; GA: gibberellic acid; CK: cytokinin; ALK: alkamides; PA: polyamines; X: other unknown molecules. Simplified overview of cell proton pumps of plant roots before (left) and after (right) HS and plant interaction in rizosphere. After HS contact, plasma membrane proton ATPase (PM H $\mathrm{H}^{+}$-ATPase) and Vacuolar $\mathrm{H}^{+}$-pyrophosphatase (V-PPase) expression enhances. Data on vacuolar $\mathrm{H}^{+}$-ATPase (V-ATPase) expression is not available in the literature. Besides expression, the rates of $\mathrm{H}^{+}$pumping/hydrolysis ratio of all three pumps appear to be increased in the presence of HS, in agreement with a higher coupling than in control plants.

stimulant" of plant growth in peat treated with soil organisms was not present in the raw peat, and also it could not be released by chemically produced soluble humates.

The organic growth-promoting substances or "auximones" were further tested in Lemna minor (known as Duckweed) plants in the presence of nutrient mineral solution (Bottomley 1917). Five treatments were applied to L. minor plants: Detmer's nutrient solution (control) supplemented or not with water extract of "bacterised peat", water extract free from "humic acid", alcoholic extract and phosphotungstic fraction. The water extract was prepared by boiling $0.5 \mathrm{~g}$ of "bacterized" peat containing the auximones in distilled water in order to extract the soluble matter from the peat. Weight of plants treated with auximones was 62 times higher than that of controls with a marked enhancement in size. Auximone treatments also presented more dense cellular issues containing larger cells, especially at the apex of young plants. Bottomley concluded that the active growth-promoting substances obtained in peat solution were derived from decomposition of organic matter, and these substances will be essential for plant development. Despite these were further confirmed using organic extracts of stable manures (Mockeridge 1920), some authors partially refuted Bottomley's conclusions about the essentiality of auximone to the plant growth (Clark 1926, Saeger 1926).

An aspect overlooked is that what Bottomley called "humic acid", was in fact a water-soluble fraction of peat after soil microorganisms action

It has been shown that these accessory food substances are produced when peat-decayed vegetable matter is acted upon by 
certain soil bacteria, and the natural inference is that during the bacterial decomposition of organic matter in the soil, that is, during humus formation, these substances are formed, hence the beneficial effect on crops of farmyard and other organic manures. (Bottomley 1914, p. 246-7).

In the 1960s, there were a sequence of works discussing the effects of HS on plant growth and physiology. Schnitzer and Poapst (1967) have showed an effect dose dependent revealed in a wide range concentration of fulvic acids extracted from a Spodosol on bean root initiation. The chemical functional groups of these HS, such as carboxylic acid and both phenolic and alcoholic hydroxyls, were reputed as responsible for part of the stimulus on plant growth. By means of acetylation of hydroxyls of fulvic acids, it was verified that root initiation was inhibited, while blocking carboxylic groups had no effect on fulvic acids ability of improving root initiation. Simultaneous blocking of those chemical groups present in fulvic acids resulted in no root initiation. The authors have concluded that phenolic groups of HS are important for root initiation processes. This is one of pioneer works in which the relationship between chemical structure and biological activity of humic compounds was first discussed.

Guminski (1968) reviewed the main information available in that time on the physiological effects of HS on plants. Guminski analyzed the results of literature in two main trends; one that claimed that HS could affect plant physiology directly and other, which stated that humic compounds may only affect plant indirectly. The direct effects would be the ones that modify plant metabolism, while the indirect effects would affect other characteristics on plant environment, such as ion uptake. Most of discussed works presented were focused on whether humus could enter plant cell or not. In this review, Guminski clarifies that even though a given fraction of HS does not penetrate the cell, it still does not mean that its fraction has no physiological activity. In addition, the discussion of direct and indirect HS action should take into account another factor, the intervention of microorganisms. In fact, this view established early that the molecular size of humus fractions should not be taken as a major factor regarding its effects on plant growth and development.

During the next decade, some authors have showed HS as very important in modifying plant growth, ions uptake and enzymes activity (Vaughan 1974, Malcolm and Vaughan 1979), and some of them observed the auxin-like mode of action (Schnitzer and Poapst 1967, O'Donell 1973). Plants were treated with humates (unfractionated), HA (with apparent HMW) or fulvic acids (with apparent LMW), and the effects on plant growth and metabolism appeared to be independent of its molecular weight at some extent. For instance, sodium humate, humic and fulvic acids have been found to promote root initiation of Pelargonium hortorum cuttings possible via an auxin-like activity (O’Donell 1973).

By means of bioassays, not only the auxin-like, but also the cytokinin-like effects were reported by Cacco and Dell'Agnola (1984). The unfractionated HS (called soluble HS) extracted from a Podsol soil were tested in a wide range from 0.1 to $100 \mathrm{mg} \mathrm{L}^{-1}$, and the plant growth regulator activity observed in the HS was suggested to be due to both a direct action and a possible increase of endogenous hormones concentration. The studies with HS so far were able to show the reputed physiological effects associated with bioassays tests, or sometimes testing plants cuttings or whole plants regarding one ion uptake. Later, the sequence of transport and enzyme steps of nitrate assimilation was evaluated in barley seedlings (Aulbuzio et al. 1986). The authors found a stimulation of nitrate uptake after 4-16 h of incubation with unfractionated HS or different molecular weight fractions at $100 \mathrm{mg} / \mathrm{L}^{-1}$ associated to a stimulus of nitrate reductase (NR), glutamate dehydrogenase (GDH) and glutamine synthetase (GS). Interesting unfractionated HS were the best treatment regarding $\mathrm{NO}_{3}$ uptake and enzymes activity. The enhanced nitrate uptake was further confirmed and the IAA-, GA-, and CK-like activities related to the LMW of HS were postulated (Dell'Agnola and Nardi 1987). Two HS fractions extracted from earthworm were studied, one with molecular weight greater and other smaller than $3,500 \mathrm{Da}$. The authors found that plant growth and $\mathrm{NO}_{3}$ uptake are differently affected by both substances, suggesting that the smaller fraction had a higher effect on plant physiology. It is worth noting that the HS used were prior treated with concentrated acetic acid, contributing to a modification of original structure of HS. In fact, organic acids (citric, malic, oxalacetic, succinic, and fumaric) at the concentration found in the root exudates of maize seedlings were able to modify the molecular size of HS (Albuzio and Ferrari 1989).

A sequence of papers corroborated the idea of the low molecular size fraction as the one endowed with greater influence on plant metabolism (Pinton et al. 1992, Muscolo et al. 1998, Nardi et al. 2000). Contrasting to the early observation by Schnitzer and Poapst (1967), which attributed the activity of fulvic acids to phenolic content, the presence of high carboxyl and aromatic $\mathrm{C}$ content in the low molecular size HS was recognized as crucial for these fractions mode of action inside the plant, influencing metabolism. On the other hand, high molecular size HS should be able to only access the cell apoplast. One might have in mind the heterogeneity of the original material utilized in each case, which may explain conflicting results.

Despite the view of inaccessibility of inner cell side by those larger humic compounds, direct positive effects on PM $\mathrm{H}^{+}$-ATPase hydrolytic activity, ATP-driven proton gradients and enzyme expression were presented later on 
(Façanha et al. 2002, Canellas et al. 2002). HA (40 $\left.\mathrm{mg} \mathrm{L}^{-1}\right)$ from earthworm compost and sewage sludge were able to influence the growth of monocots and dicots plants via the activation of $\mathrm{PM} \mathrm{H}^{+}$-ATPase, which was proposed as a possible metabolic marker for biological activity of HS. By means of Gas Chromatography/Mass Spectrometry (GC/MS), it was possible to identify IAA molecules into HA structure. The authors have speculated that the either humic-IAA groups could access plant receptors, besides activate transcription factors and protein synthesis; at the same time, they could modulate the activity of $\mathrm{PM} \mathrm{H}^{+}$-ATPase, resulting physiological responses such as root cell division and growth. Curiously, however, these findings were also true to low molecular HS effects (Quaggiotti et al. 2004). In addition to the previous HS effects in maize roots, it was also shown long-distance effects in shoots in respect of nitrogen uptake by transcript accumulation of $\mathrm{NO}_{3}$ transporter and $\mathrm{PM} \mathrm{H}^{+}$-ATPase. The findings of Canellas et al. (2002) and Quaggiotti et al. (2004) were rather complementary since the first one pointed the mitotic sites precursors of maize lateral roots, rich in $\mathrm{PM} \mathrm{H}^{+}$-ATPase (2-fold higher than controls), while the second have shown the increase ( 8 -fold) of the mRNA levels also in maize roots (MHA2 transcript accumulation). Both works found IAA in HS structure by different methods; corroborating the idea that the humus ability of interfering in plant biochemistry and physiology is not directly related to its relative molecular mass, but to its putative general hormones or other "accessories" content.

In this regard, HS of both relative high and low molecular mass isolated from different sources in several exposure times and concentrations were able to exert its hormone-like activity in maize, tomato, Arabidopsis and cucumber (Dobbss et al. 2007, Zandonadi et al. 2007, Carletti et al. 2008, Elena et al. 2009, Mora et al. 2010, Schiavon et al. 2010, Zandonadi et al. 2010, Trevisan et al. 2011, Mora et al. 2012). The problem of comparing these and others results in the literature is the heterogeneity of HS extraction methods and chemical characteristics, and also the plant treatment approaches. Yet recent independently obtained results point out to one same direction: humus effects on plant physiology are justified only by the auxin-like effect. Indeed there seems to be a complex signals network interaction, at some extent independent of auxin (Dobbss et al. 2007, Schmidt et al. 2007, Zandonadi et al. 2010, Mora et al. 2012). Water-extractable soil HS altered development in Arabidopsis roots, inducing an increase in root hair density in IAA-independent manner as shown by the lack of responsiveness of the DR5 constructs containing auxin-response element (Schmidt et al. 2007). On the other hand, Arabidopsis root development was also shown to be altered by both high $(>14,000 \mathrm{Da})$ and low $(<700 \mathrm{Da})$ molecular weight
HS, in an auxin-like mode (Dobbss et al. 2007). Nevertheless, the same authors have found an unusual auxin response (growth of primary root), as previously reported (Zandonadi et al. 2007). In fact, other important signal, partially independent of auxin, such as nitric oxide, is induced by HA (Zandonadi et al. 2010, Mora et al. 2012). Possibly, the root hair enhancement induced by HS observed by Schmidt et al. (2007) did not affect auxin report genes due to nitric oxide-induced hair emergence rather than auxin directly. Since nitric oxide is also induced by Alkamides in sites of adventitious root proliferation (Campos-Cuevas et al. 2008) and lateral root site (Méndez-Bravo et al. 2010), HS might have chemical groups similar to these molecules (Canellas et al. unpublished). This new scenario remains to be more explored, but for now it seems

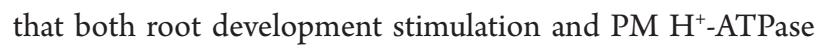
activation elicited by exogenous IAA and HS depend essentially on mechanisms that use $\mathrm{NO}$ as a messenger.

Hormonal humic substances content: The presence and relevance of hormonal molecules in HS macrostructure has been a quite controversial issue, inducing several scientific questions, such as: Are there any specific set of hormonal molecules present in all bioactive HS? Would the HS bioactivity derived only from their hormonal content? If do so, are these hormones originated from microorganisms of humus or are they resultant of a HS chemical crosstalk with the root system too? Does humus influence hormone production in plants? Those are hard questions to answer, which will require systematic and integrated scientific efforts to be elucidated. Although there is a body of evidences showing that auxin response factors are sensitive to humic matter and nitric oxide, endogenous hormones production as affected by humus remains to be clarified.

Apparently, the auxin-like activity of low molecular HS observed earlier by Dell'Agnola and Nardi (1987) was related to the presence of IAA (Muscolo et al. 1998). These authors showed that the concentrations of IAA in HS were estimated to be $0.5 \%(\mathrm{w} / \mathrm{w})$ by enzyme immunoassay and 2 to $3.7 \%$ by radioimmunoassay.

The hormone-like activity of HS may also be associated to other molecules (Young and Chen, 1997). Purified HA from different sources contain polyamines, putrescine, spermidine, and spermine in the range of 1.54-7.00, 0.39-3.88, $0.48-4.79 \mathrm{nmol} \mathrm{g}^{-1}$, respectively, by means of High Performance Liquid Chromatography (HPLC).

Later, the presence of IAA molecules into high molecular HA was found by means of gas chromatography mass spectrometry (Canellas et al. 2002). Quaggioti et al. (2004) have found $37 \mathrm{nmol} \mathrm{mg}^{-1} \mathrm{C}$, corresponding to a final concentration of $27.75 \mathrm{nM}$ in the $0.75 \mathrm{mg} \mathrm{C} \mathrm{L}^{-1}$ in low molecular size HS used in the experiments. 
Schiavon (2010) have confirmed previously detection of IAA in high molecular $\mathrm{HS}(>3.5 \mathrm{kDa})$ from vermicompost and found a concentration of $27 \mathrm{nmol}$ per $\mathrm{mg}$ of $\mathrm{C}$, very similar to what was verified in low molecular HS (Quaggioti et al. 2004). Such a low IAA concentration was evidenced to be very effective in stimulating the plasmalemma and tonoplast proton pumps during maize seedlings root development (Zandonadi et al. 2007, 2010). Nevertheless, HA at $20 \mathrm{mg} \mathrm{C} \mathrm{L}^{-1}$ were more effective than IAA, indicating that the concerted activation of the PM $\mathrm{H}^{+}$-ATPase, vacuolar $(\mathrm{V}) \mathrm{H}^{+}$-ATPase and $\mathrm{H}^{+}$-PPase and promotion of root development may involve more signals derived/induced by HS.

Zandonadi et al. (2010) extended the view of physiological activity of HS by using IAA signaling and transport inhibitors, and NO scavengers and inductors showing the NO role in lateral roots development and on the differential proton pumps activation. The observations of the IAA inhibitors on HS effects were further confirmed (Trevisan et al. 2011). The mRNA transcript accumulation of genes encoding PM $\mathrm{H}^{+}$-ATPase and the enzyme activity was also further studied, confirming some specific effects of HA in plant bioenergetics and nutrient acquisition (Elena et al. 2009, Mora et al. 2010). Moreover, HA could alter cytokinins, polyamines and abscisic acid in plants (Mora et al. 2010).

Interestingly, the hormone-like effects observed by the aforementioned works were valid either in nutrient-free or nutrient-complete treatment solutions. Recently, the complexity of hormone interactions during $\mathrm{HA}$ action in plants was reported to involve not only auxin and NO, but also ethylene (Mora et al. 2012). Moreover, short-term treatment (30 or 120

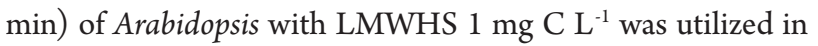
a transcriptomic approach whose results lead to the following conclusions: HS exert their function on plant physiology partially via auxin activity, but also by interfering with other response signaling (Trevisan et al. 2011).

Recently, it was found $185 \mathrm{ng} \mathrm{L}^{-1}$ of N-indole-3-acetic acid, cytokinin, and gibberellins in food waste-based vermicompost tea (Arancon et al. 2012). This HS-rich tea enhanced the germination velocity of tomato seeds when soaked at lower concentrations.

In spite of the accumulated data on the capacity of HS to express hormone-like bioactivities, there has been some data that point out to direct physiological effects of HA per se, as promoted by its core structure, rather than by any hormonal molecule associated to the HS macrostructure (Elena et al. 2009, Mora et al. 2012). According to these authors, there were undetectable concentrations of IAA, ABA and GA in the HA extracted from leonardite as analyzed by means of liquid chromatography-mass spectrometry quantification. Previously,
Chen et al. (2004) argued that HS could not provide phytohormones as those could not be retained in the HS structure after the extensive extraction and purification processes needed to isolate the bioactive HS fractions. In this context, the physiological effects observed in HS-treated plant would be related to the release of micronutrients rather than to phytohormones. Conversely, several works successfully showed a number of HA effects on plant physiology in the absence of any nutritional influence but retaining many similarities with the hormonal modes of action (Façanha et al. 2002, Dobbss et al. 2007, Zandonadi et al. 2007). Such a controversy on the molecular nature of the HS bioactivity seems far to be definitely solved, but it is possible that different HS fractions isolated from highly variable sources and submitted to diverse extraction procedures have indeed to support their bioactivities in quite different bases.

Proton pumps HS activation: Despite intense research efforts, the long standing puzzle of HS molecular mechanism of action on plant cell growth regulation remains elusive. However, two discoveries provided major insights into this complex biochemical machinery of HA bioactivity. First, it was demonstrated that the $\mathrm{PM} \mathrm{H}^{+}$-ATPase functional expression is induced by HA, positively influencing the nutrient uptake and root morphogenesis (Canellas et al. 2002, Façanha et al. 2002, Elena et al. 2009). Second, this phenomenon was found to occur upon $\mathrm{HA}$ /auxins control in concerted with a differential activation of the vacuolar proton pumps, exerting a crucial role in plant cell vacuolation and in root cell expansion (Zandonadi et al. 2007).

The classical physiological roles of the $\mathrm{H}^{+}$-pumps derive from their capacity to: (a) transform metabolic energy into proton motive force at the plasmalemma and the tonoplast; (b) influence $\mathrm{H}^{+}$concentration in the free space, in the cytoplasm, and in the vacuole (Marré and Ballarin-Denti 1985); and $(c)$ acidify the apoplast promoting cell wall loosening required for the plant cell growth (Rayle and Cleland 1970, Hager et al. 1971). Hager et al. (1971) proposed that hydrogen ions could act as a second messenger between the site of auxin action, and the site of wall loosening, showing the possible role of auxin-induced acidification on cell elongation. From this classical work, the acid-growth theory was stated: "auxin activates the $\mathrm{H}^{+}$-pumping ATPase at the plasma membrane (PM), which utilizes ATP to raise the proton concentration in the cell wall. This event leads to an increase in the activity of enzymes that soften the cell wall and thus trigger cell elongation. The transport of protons into the cell wall is compensated by a flow of cations into the interior of the cytoplasm, thus causing secondary auxin effects". 
Taking in mind this background, it makes clearer the interpretation of most of the previous data on the hormone-like HS activities and their effects on $\mathrm{H}^{+}$-ATPases. Thus, it will be perhaps not surprising that low concentrations of $\mathrm{HA}\left(10,25\right.$ and $\left.50 \mathrm{mg} \mathrm{L}^{-1}\right)$ enhance the increase in length of excise pea root segments around $50 \%$, while higher concentrations (above $100 \mathrm{mg} \mathrm{L}^{-1}$ ) inhibited it after $18 \mathrm{~h}$ (Vaughan 1974), somewhat similar to auxin effects stated by the acid-growth theory. In addition, the molecular weight of HS, its concentration and the time of plant exposure affect ions uptake and enzyme activity (Maggioni et al. 1987). For instance, the uptake rate of potassium and sulphate in $A$. sativa roots treated for $8 \mathrm{~h}$ with unfractionated HS (50 mg C $\mathrm{L}^{-1}$ ) enhanced, respectively, 33 and $106 \%$. The authors also found that cell membrane could be the first site of action of HS, and suggested the possible role of carboxylic groups with plasma membrane ATPase activity, resuming the discussion on structure-activity relationships of HS and launching the role of this enzyme in HS mode of action.

Pinton et al. (1992) reported similar effects on PM ATPase activity in oat roots treated with LMWHS at low concentration $\left(0.5 \mathrm{mg} \mathrm{C} \mathrm{L}^{-1}\right)$, and expanded the view of proton pumps role in HS mechanism of action, showing that vacuolar membrane is also sensitive to HS. In line with this idea, the PM $\mathrm{H}^{+}$-ATPase activity in membrane vesicles isolated from oat plants was positively affected in the presence of LMWHS at $0.25,0.5$ and $0.75 \mathrm{mg} \mathrm{C} \mathrm{L}^{-1}$, while $1.0 \mathrm{mg} \mathrm{C} \mathrm{L}^{-1}$ inhibited the enzyme activity. This work confirmed previous findings on the $\mathrm{PM} \mathrm{H}^{+}$-ATPase activation in the presence of HS (Maggioni et al. 1987) and was the first to measure the V-ATPase activity in tonoplast enriched vesicles incubated with HS. The same group further tested the effects of HMW humic fraction in comparison to LMW humic fractions on PM $\mathrm{H}^{+}$-ATPase activity (Varanini et al. 1993). The authors showed a direct effect of LMWHS stimulating PM H $\mathrm{H}^{+}$-ATPase activity, while HMWHS decreased the enzyme activity and intravesicular proton accumulation. Based on these results, it was suggested that the stimulatory effect of soil HS on plant nutrition and growth was related to direct action of LMWHS on PM $\mathrm{H}^{+}$-ATPase and cell membrane permeability. The organic matter fractions studied was postulated to play a role in plant-soil interaction improving plant growth and nutrition.

There are only two works showing the effects of HS on tonoplast $\mathrm{H}^{+}$pumps (Pinton et al. 1992, Zandonadi et al. 2007). Zandonadi et al. (2007) highlighted the crucial function of the three pumps for the acid growth mediated by both humic and indole acetic acids. Moreover, $\mathrm{H}^{+}$-PPase was proved to be more sensitive to IAA, according to the key role of this enzyme during auxin transport and organogenesis ( $\mathrm{Li}$ et al.
2005). HS treatment was able to increase coupling of enzymes studied, an important effect for plant metabolism.

Trevisan etal. (2011) suggested that HS target gene transcription and protein regulation. The low molecular HS tested could interfere in vesicle trafficking and transport mechanisms. This information is very important to discuss the HS-mediated effect on proton pumps and plant physiology. The overexpression of vacuolar $\mathrm{H}^{+}$-PPase resulted in increase of both auxin fluxes and $\mathrm{PM} \mathrm{H}^{+}$-ATPase abundance ( $\mathrm{Li}$ et al. 2005). Interestingly, from these results, a novel crucial role of $\mathrm{H}^{+}$-PPase on rhizosphere acidification, and thus nutrient uptake are brought up (Yang et al. 2007, Paez-Valencia et al. 2013).

\section{TECHNOLOGIES AND COMMERCIAL USE OF HUMIC SUBSTANCES}

One of the most promising uses for HS based fertilizers will be in the improvement of plant production in stress conditions. Despite the plethora of new products claimed to be HS based/enriched, recommended to improve plant yield, it is important keep in mind that HS are not chemically well-determined molecules, but rather they are very complex macrostructures formed by many different molecular aggregates. This depicts a very complex scenario in which many direct and indirect effects on plant growth should be considered in order to properly provide some HS product recommendation. Environmental issues such as the HS properties to improve the soil physical and chemical conditions have to be analyzed in conjunction with their effects on plant physiology and biochemistry, enhancing the major nutrient transport systems and also playing an important role as hormone-like substances. Furthermore, most isolated HS per se have no or only few nutrients attached in their macrostructure and the soil or substrate cultivated with it needs to have a proper management to preserve organic matter and microorganisms. However, some HS-based products can be enriched with mineral nutrients and improve their effects on plant growth. In some conditions, farmers may also use, when available, earthworm composting and biofertilizers (e.g. products based on Effective Microorganisms) to preserve humified organic matter into soils and guarantee the level of nutrients and other biochemical features. This is especially important to tropical and subtropical regions, where the majority of soils are high weathered and naturally poor in organic matter content (Lopes and Cox 1977). Occasionally, the organic matter is even lower due a wrong soil management (Pimentel et al. 1995).

Unfractionated HS, such as Na-humates, were reported as important to plant growth and nucleic acids metabolism (Fialová 1969). Interestingly, it was observed that the pre-cultivation of wheat plants in Na-humate resulted in intensive growth 
of roots and RNA accumulation in wheat. The author suggested that this could be a result from HS effects on enhancement of nutrient uptake, functioning as growth regulators. The use in field conditions was mentioned as a concrete possibility.

The proper management of soil, and the use of ecofriendly technologies might be sustainable alternatives for improve positive effects of HS in agriculture. In fact, there are HS-rich products that may reduce the overuse of high soluble fertilizers, due the improvement of root development and therefore nutrient uptake (Gutiérrez-Miceli et al. 2011, Yadav and Garg 2011, Arancon et al. 2012, Zandonadi and Busato 2012). For example, the leachate derived from vermicomposting (called worm-bed leachate) is highly valuable as plant growth promoter, enhancing production of vegetables (Gutiérrez-Miceli et al. 2011, Zandonadi and Busato 2012). This is a safe and efficient technology, very important due the recycling of different organic wastes and reduction of fertilizer overuse. The use of the aqueous extract of vermicompost, known also as vermicompost tea, is also an exceptional technology for improvement of plant growth and production (Arancon et al. 2012). As mentioned for compost tea used by Vaccaro et al. (2009), the presence of HS and phytohormones, such as auxin, cytokinin and gibberellin in vermicompost water extract, may justify additionally its nutrient content, why these products may act modulating plant growth.

In conclusion, it seems clear that any real sustainable pathways for the improvement of HS based technologies in agriculture will need also to involve a proper management of soil, and the use of ecofriendly technologies such as composting, vermicomposting, biofertilizers and green manure. For while, the correct use of these and related agriculture practices will continue to be important as both economical and ecological way to increase the soil organic matter content,

\section{REFERENCES}

Albuzio A, Ferrari G (1989) Modulation of the molecular size of humic substances by organic acids of the root exudates. Plant Soil 113:237-241.

Arancon NQ, Pant A, Radovich T, Hue NV, Potter JK, Converse CE (2012) Seed germination and seedling growth of tomato and lettuce as affected by vermicompost water extracts (Teas). HortScience 47:1722-1728.

Arteaga M, Garcés N, Novo R, Guridi F, Pino JA, Acosta M, Pasos M, Besú D (2007) Influencia de la aplicación foliar del bioestimulante Liplant sobre algunos indicadores biológicos del suelo. Revista de Protección Vegetal 22:110-117.

Bottomley WB (1914) Some accessory factors in plant growth and nutrition. Proceedings of the Royal Society of London-B $88: 237-247$

Bottomley WB (1915) A bacterial test for plant food accessories: enriching it with microorganisms and HS, providing a constant natural source of plant growth regulators and nutrients.

\section{CONCLUDING REMARKS}

In an ecological and agronomical point of view, there is no "soluble" HA isolated in natural environments. Essentially, most knowledge obtained with these experimental fractions (soluble in $\mathrm{NaOH}$ or $\mathrm{KOH}$ solutions) should be considered mainly as instrumental to reveal a component of organic matter that might be used as an appropriate quality marker of soil environment or HS-based fertilizers. Concerning HS industry, the HS products may need more research results of an international approved and integrated method that would be accurate not only measuring humic fractions content, but also its efficacy on improving plant growth. Regarding the scientific approaches on plant-HS interactions, focus should be given also in the water- or the plant organic acids-soluble fractions in both industrial humic products and soils- or residues-derived HS. Therefore, it is important to have a standard method that could be used by different researchers in order to accomplish an efficient comparison of results in a diversity of HS sources and plant species. Efforts should be directed towards the development of a biochemically standardized, technically accessible, and economically viable method to qualify the organic matter bioactivity.

\section{ACKNOWLEDGEMENTS}

We gratefully acknowledge Dr. Ítalo Moraes Rocha Guedes (Embrapa Hortaliças) for revision and discussion of the manuscript and the National Counsel of Technological and Scientific Development (CNPq) for the financial support.

(auximones). Proceedings of the Royal Society of London-B 89:102-108

Bottomley WB (1917) Some effects of organic growth-promoting substances: (auximones) on the growth of Lemna minor in mineral culture solutions. Proceedings of the Royal Society of London-B 89:481-507.

Busato JG, Lima L, Aguiar NO, Canellas LP, Olivares FL (2012) Changes in labile phosphorus forms during maturation of vermicompost enriched with phosphorus-solubilizing and diazotrophic bacteria. Bioresource Technology 110:390-395.

Cacco G, Dell'Agnola G (1984) Plant growth regulator activity of soluble humic complex. Canadian Journal of Soil Science 62:306-310.

Cameron RS, Thornton BK, Swift RS, Posner AM (1972) Molecular weight and shape of humic acid from sedimentation and diffusion 
measurements on fractionated extracts. Journal of Soil Science 23:394-408.

Campos-Cuevas JC, Pelagio-Flores R, Raya-González J, MéndezBravo A, Ortiz-Castro R, López-Bucio J (2008) Tissue culture of Arabidopsis thaliana explants reveals a stimulatory effect of alkamides on adventitious root formation and nitric oxide accumulation. Plant Science 174:165-173.

Canellas LP, Olivares FL, Okorokova-Façanha AL, Façanha AR (2002) Humic acids isolated from earthworm compost enhance root elongation, lateral root emergence, and plasma membrane $\mathrm{H}^{+}$-ATPase activity in maize roots. Plant Physiology 130:1951-1957.

Canellas LP, Zandonadi DB, Busato JG, Baldotto MA, Simões ML, Martin-Neto L, Façanha AR, Spaccini R, Piccolo A (2008a) Bioactivity and chemical characteristics of humic acids from tropical soils sequence. Soil Science 173:624-637.

Canellas LP, Teixeira Junior LRL, Dobbss LB, Silva CA, Medici LO, Zandonadi DB, Facanha AR (2008b) Humic acids cross interactions with root and organic acids. Annals of Applied Biology 153:157-166.

Carletti P, Masi A, Spolaore B, De Laureto PP, De Zorzi M, Turetta L, Ferretti M, Nardi S (2008) Protein expression changes in maize roots in response to humic substances. Journal of Chemical Ecology 34:804-818.

Chen Y, Aviad T (1990) Effects of humic substances on plant growth. In: MacCarthy P, Clapp CE, Malcom RL, Bloom PR (Eds.), Humic substances in soils and crop science: selected readings. Soil Science Society of America, Madison, pp.161-186.

Chen Y, Clapp CE, Magen H (2004) Mechanisms of plant growth stimulation by humic substances: The role of organo-iron complexes. Soil Science and Plant Nutrition 50:1089-1095.

Clark NA (1926) Plant growth promoting substances, hydrogen ion concentration and the reproduction of Lemna. Plant Physiology 1:273.

Darwin C (1880) The power of movement in plants. John Murray, London.

Darwin C (1881) The formation of vegetable mould through the action of worms with some observations on their habits. John Murray, London.

Dell'Agnola G, Nardi S (1987) Hormone-like effect and enhanced nitrate uptake induced by depolycondensed humic fractions obtained from Allolobophoru rosea and A. caliginosa faeces. Biology and Fertility of Soils 4:115-118.

Dobbss LB, Medici LO, Peres LEP, Pino-Nunes LE, Rumjanek VM, Façanha AR, Canellas LP (2007) Changes in root development of Arabidopsis promoted by organic matter from oxisols. Annals of Applied Biology 151:199-211.

Elena A, Diane L, Eva B, Marta F, Roberto B, Zamarreño M, GarcíaMina JM (2009) The root application of a purified leonardite humic acid modifies the transcriptional regulation of the main physiological root responses to Fe deficiency in Fe-sufficient cucumber plants. Plant Physiology and Biochemistry 47:215-223.

Façanha AR, Façanha ALO, Olivares FL, Guridi F, Santos GA, Velloso ACX, Rumjanek VM, Brasil F, Schripsema J, Braz-Filho R, Oliveira
MA, Canellas LP (2002) Bioatividade de ácidos húmicos: efeito sobre o desenvolvimento radicular e sobre a bomba de prótons da membrana plasmática. Pesquisa Agropecuária Brasileira 37:1301-1310.

FAO (2010) Trends in sustainable development. Chemicals, mining, transport and waste management 2010-2011. United Nations, New York.

Fialová S (1969) Influence of sodium humate and nutritive conditions on the content of nucleic acids, particularly on the ribosomal ribonucleic acid in wheat root. Biologia Plantarum 11:8-22.

Finance ministry, Secretariat for Economic Monitoring (2011) Panorama do mercado de fertilizantes, Maio/2011. Available at: www.seae.fazenda.gov.br.

Frías I, Caldeira MT, Pérez-Castiñeira JR, Navarro-Aviñó JP, Culiañez-Maciá FA, Kuppinger 0 , Stransky $H$, Pagés M, Hager A, Serrano R (1996) A major isoform of the maize plasma membrane $\mathrm{H}(+)$-ATPase: characterization and induction by auxin in coleoptiles. Plant Cell 8:1533-1544.

Gaxiola RA, Sanchez CA, Paez-Valencia J, Ayre BG, Elser JJ (2012). Genetic manipulation of a vacuolar $\mathrm{H}^{+}$-PPase: from salt tolerance to yield enhancement under phosphorus-deficient soils. Plant Physiology 159:3-11.

Gaxiola RA, Palmgren MG, Schumacher K (2007) Plant proton pumps. FEBS Letters 581:2204-2214.

Guminski S (1968) Present-day views on physiological effects induced in plant organisms by humic compounds. Soviet Soil Science 9:1250-1256.

Gutiérrez-Miceli FA, Llaven MAO, Nazar PM, Sesma BR, ÁlvarezSolís JD, Dendooven L (2011) Optimization of vermicompost and worm-bed leachate for the organic cultivation of radish. Journal of Plant Nutrition 34:1642-1653.

Hager A, Menzel H, Krauss A (1971) Experiments and hypothesis concerning the primary action of auxin in elongation growth. Planta 100:47-75.

Herder GD, Van Isterdael G, Beeckman T, De Smet I (2010) The roots of a new green revolution. Trends in Plant Science 15:600-607.

Hoben JP, Gehl RJ, Millar N, Grace PR, Robertson GP (2011) Non-linear nitrous oxide $\left(\mathrm{N}_{2} \mathrm{O}\right)$ response to nitrogen fertilizer in on-farm corn crops of the U.S. Midwest. Global Change Biology 17:1140-1152.

Kogl F, Haagen-Smit A J (1931) Uber die chemie des wuchsstoffs. Proceedings of the Koninklijke Nederlandse Akademie Van Wetenschappen 34:1411-1416.

Instituto de Pesquisa Econômica Aplicada (IPEA) Comunicado $n^{\circ} 145$ - Plano Nacional de Resíduos Sólidos: diagnóstico dos resíduos urbanos, agrosilvopastoris e a questão dos catadores. Avaiable at: http://www.ipea.gov.br/portal/images/stories/ PDFs/comunicado/120425_comunicadoipea0145.pdf

Li J, Yang H, Peer WA, Richter G, Blakeslee J, Bandyopadhyay A, Titapiwantakun B, Undurraga S, Khodakovskaya M, Richards EL, Krizek B, Murphy AS, Gilroy S, Gaxiola R (2005) Arabidopsis $\mathrm{H}^{+}$-PPase AVP1 regulates auxin-mediated organ development. Science. 310:121-125. 
Lopes AS, Cox FR (1977) A survey of the fertility status of surface soils under 'cerrado' vegetation in Brazil. Soil Science Society of America Journal J 41:741-747.

Maggioni A, Varanini Z, Nardi S, Pinton R (1987) Action of soil humic matter on plant roots: Stimulation of ion uptake and effects on $\left(\mathrm{Mg}^{2+} / \mathrm{K}^{+}\right)$ATPase activity. Science of the Total Environment 62:355-363.

Malcom RE, Vaughan D (1979) Humic substances and phosphatase activities in plant tissues. Soil Biology and Biochemistry 11:253-259.

Marré E, Ballarin-Denti A (1985) The proton pumps of the plasmalemma and the tonoplast of higher plants. Journal of Bioenergetics and Biomembranes 17:1-21.

Mendez-Bravo A, Raya-Gonzalez J, Herrera-Estrella L, LopezBucio J (2010) Nitric oxide is involved in alkamide-induced lateral root development in arabidopsis. Plant and Cell Physiology 51:1612-1626.

Mockeridge FA (1920) The occurrence and nature of the plant growth-promoting substances in various organic manurial composts. Biochemical Journal 14:432.

Mora V, Bacaicoa E, Zamarreño, AM, Aguirre E, Garnica M, Fuentes M, García-Mina JM (2010) Action of humic acid on promotion of cucumber shoot growth involves nitrate-related changes associated with the root-to-shoot distribution of cytokinins, polyamines and mineral nutrients. Journal of Plant Physiology 167:633-642.

Mora V, Baigorri R, Bacaicoa E, Zamarreñob AM, García-Mina JM (2012) The humic acid-induced changes in the root concentration of nitric oxide, IAA and ethylene do not explain the changes in root architecture caused by humic acid in cucumber. Environmental and Experimental Botany 76:24-32.

Muscolo A, Cutrupi S, Nardi S (1998) IAA detection in humic substances. Soil Biology and Biochemistry 30:1199-1201.

Nardi S, Pizzeghello D, Gessa C, Ferrarese L, Trainotti L, Casadoro $\mathrm{G}$ (2000) A low molecular weight humic fraction on nitrate uptake and protein synthesis in maize seedlings. Soil Biology and Biochemistry 32:415-420.

Nardi S, Tosoni M, Pizzeghello D, Provenzano MR, Cilenti A, Sturaro A, Rella R, Vianello A (2005) Chemical characteristics and biological activity of organic substances extracted from soils by root exudates. Soil Science Society of American Journal 69:2012-2019.

Nardi S, Muscolo A, Vaccaro S. Baiano S, Spaccini R, Piccolo A (2007) Relationship between molecular characteristics of soil humic fractions and glycolytic pathway and Krebs cycle in maize seedlings. Soil Biology and Biochemistry 39:3138-3146.

Novotny V (2011) The danger of hypertrophic status of water supply impoundments resulting from excessive nutrient loads from agricultural and other sources. Journal of Water Sustainability 1:1-12.

O'Donnell RW (1973) The auxin-like effects of humic preparations from leonardite. Soil Science 116:106-112.

Orlov DS, Ammosova YM, Glebova GI (1975) Molecular parameters of humic acids. Geoderma 13:211-229.
Ortega R, Fernández M (2007) Agronomic evaluation of liquid humus derived from earthworm humic substances. Journal of Plant Nutrition 30:2091-2104.

Paez-Valencia J, Sanchez-Lares J, Marsh E, Dorneles LT, Santos MP, Sanchez D, Winter A, Murphy S, Cox J, Trzaska M, Metler J, Kozic A, Façanha AR, Schachtman D, Sanchez CA, Gaxiola RA (2013). Enhanced proton translocating pyrophosphatase activity improves nitrogen use efficiency in romaine lettuce. Plant Physiology 161:1557-1569.

Palmgren MG (2001) Plant plasma membrane $\mathrm{H}^{+}$-ATPase: powerhouses for nutrient uptake. Annual Review of Plant Physiology and Plant Molecular Biology 52:817-845.

Piccolo A (1996) Humus and soil conservation. In: Piccolo A (Ed.) Humic substances in terrestrial ecosystems. Elsevier, Amsterdam. pp.225-264

Piccolo A (2001) The supramolecular structure of humic substances. Soil Science 166:810-832.

Piccolo A, Spaccini R, Nieder R, Richter J (2004) Sequestration of a biologically labile organic carbon in soils by humified organic matter. Climatic Change 67:329-343.

Pimentel D, Harvey C, Resosudarmos P, Sinclair K, Kurz D, McNais M, Crist S, Shpritz L, Fitton L, Saffouri R, Blair R (1995) Environmental and economic cost of soil erosion and conservation benefits. Science 267:1117-1123.

Pinton R, Varanini Z, Vizzotto G, Maggioni A (1992) Soil humic substances affect transport properties of tonoplast vesicles isolated from oat roots. Plant and Soil 142:203-210.

Pinton R, Cesco S, De Nobili M, Santi S, Varanini Z (1998) Waterand pyrophosphate-extractable humic substances fractions as a source of iron for Fe-deficient cucumber plants. Biology and Fertility of Soils 26:23-27.

Pinton R, Cesco S, lacolettig G, Astolfi S, Varanini Z (1999) Modulation of $\mathrm{NO}^{3-u p t a k e}$ by water-extractable humic substances: involvement of root plasma membrane $\mathrm{H}^{+}$ATPase. Plant and Soil 215:155-161.

Quaggiotti S, Ruperti B, Pizzeghello D, Francioso O, Tugnoli V, Nardi S (2004) Effect of low molecular size humic substances on nitrate uptake and expression of genes involved in nitrate transport in maize (Zea mays L.). Journal of Experimental Botany 55:803-813.

Rayle DL, Cleland R (1970) Enhancement of wall loosening and elongation by acid solutions. Plant Physiology 46:250-253.

Saeger A (1926) The growth of duckweeds in mineral nutrient solutions with and without organic extracts. The Journal of General Physiology 7:517-526.

Schiavon M, Pizzeghello D, Muscolo A, Vaccaro S, Francioso O, Nardi S (2010) High molecular size humic substances enhance phenylpropanoid metabolism in maize (Zea mays L.). Journal of Chemical Ecology 36:662-669.

Schmidt W, Santi S, Pinton R, Varanini Z (2007) Waterextractable humic substances alter root development and epidermal cell pattern in Arabidopsis. Plant and Soil 300:259-267. 
Schnitzer M, Poapst PA (1967) Effects of a soil humic compound on root initiation. Nature 11:598-599.

Serrano R (1989) Structure and function of plasma membrane ATPase. Annual Review of Plant Physiology and Plant Molecular Biology 40:61-94.

Simpson AJ, Kingery WL, Hayes MHB, Spraul M, Humpfer E, Dvortsak P, Kerssebaum R, Godejohann M, Hofmann M (2002) Molecular structures and associations of humic substances in the terrestrial environment. Naturwissenschaften 89:84-88.

Steinberg CEW, Kamara S, Prokhotskaya V, Manusadžianas L, Karasyova TA, Timofeyev MA, Jie Z, Paul A, Meinelt T, Farjalla VF, Matsuo AYO, Burnison BK, Menzel R (2006) Dissolved humic substances - ecological driving forces from the individual to the ecosystem level? Freshwater Biology 51:1189-1210.

Stevenson FJ (1994) Humus chemistry: genesis, composition, reactions. $2^{\text {nd }}$ ed. John Wiley and Sons, New York.

Swarup R, Parry G, Graham N, Allen T, Bennett MJ (2002) Auxin crosstalk: integration of signalling pathways to control plant development. Plant Molecular Biology 49:411-426.

Tomasi N, Nobili M, Gottardi S, Zanin L, Mimmo T, Varanini Z, Römheld V, Pinton R, Cesco S (2013) Physiological and molecular characterization of Fe acquisition by tomato plants from natural Fe complexes. Biology and Fertility of Soils 49:187-200.

Trevisan S, Botton A, Vaccaro S, Vezzaro A, Quaggiotti S, Nardi S (2011) Humic substances affect Arabidopsis physiology by altering the expression of genes involved in primary metabolism, growth and development. Environmental and Experimental Botany 74:45-55.

Vaccaro S, Muscolo A, Pizzeghello D, Spaccini R, Piccolo A, Nardi $S$ (2009) Effect of a compost and its water-soluble fractions on key enzymes of nitrogen metabolism in maize seedlings. Journal of Agricultural and Food Chemistry 57:11267-11276.

Varanini Z, Pinton R, De Biasi MG, Astolfi S, Maggioni A (1993) Low molecular weight humic substances stimulate $\mathrm{H}^{+}$-ATPase activity of plasma membrane vesicles isolated from oat (Avena sativa L.) roots. Plant and Soil 153:61-69.
Vaughan D (1974) A possible mechanism for humic acid action on cell elongation in root segments of Pisum sativum under aseptic conditions. Soil Biology Biochemistry 6:241-247.

Vaughan D, Malcolm RE (1979) Effect of humic acid on invertase synthesis in roots of higher plants. Soil Biology Biochemistry 11:247-272.

Vaughan D, Malcolm RE (1985) Influence of humic substances on growth and physiological process. In: Vaughan D, Malcolm RE (Eds.) Soil organic matter and biological activity. Kluwer Academic Publishers, Dordrecht, pp.37-75.

Went FW (1926) On growth-accelerating substances in the coleoptile of Avena sativa. Proceedings of the Koninklijke Nederlandse Akademie Van Wetenschappen 30:10-19.

Whitehead DC (1963) Some aspects of the influence of organic matter on soil fertility. Soil Fertil 26:217-223.

Yadav A, Garg VK (2011) Recycling of organic wastes by employing Eisenia fetida. Bioresource Technology 102:2874-2880.

Yang H, Knapp J, Koirala, P, Rajagopal D, Peer WA, Silbart L, Murphy A, Gaxiola R (2007) Enhanced phosphorus nutrition in monocots and dicots over-expressing a phosphorus-responsive type I $\mathrm{H}^{+}$-pyrophosphatase. Plant Biotechnology J 5:735-745.

Young CC, Chen LF (1997) Polyamines in humic acid and their effect on radical growth of lettuce seedlings. Plant Soil 195(1):143-149.

Zandonadi DB, Busato JG (2012) Vermicompost humic substances: technology for converting pollution into plant growth regulators. IJESER 3:73-84.

Zandonadi DB, Canellas LP, Façanha AR (2007) Indolacetic and humic acids induce lateral root development through a concerted plasmalemma and tonoplast $\mathrm{H}^{+}$-pumps activation. Planta 225:1583-1595.

Zandonadi DB, Santos MP, Dobbss LB, Olivares FL, Canellas LP, Binzel ML Okorokova-Façanha AL, Façanha AR (2010) Nitric oxide mediates humic acids-induced root development and plasma membrane $\mathrm{H}^{+}$-ATPase activation. Planta 231:1025-1036. 